\title{
Analiza konstrukcji i opracowanie geometrii narzędzi do zgrzewania złączy ze stopów metali metodą FSW
}

\author{
Analysis of tool structure and development of tool geometry \\ for joining metallic alloys using FSW methods
}

\section{Streszczenie}

Dotychczasowe badania nad geometrią tzn. kształtem pól poprzecznych oraz pobocznic i opór narzędzi do zgrzewania FSW/FSSW (FSW-Friction Stir Welding, FSSW - Friction Stir Spot Welding) przebiegają zazwyczaj metodą prób i błędów oraz idei wynikłych z różnego rodzaju przypadków badawczych. Niniejszy artykuł może być podstawą matematycznego uporządkowania typoszeregów narzędzi przeznaczonych do zgrzewania materiałów o różnych właściwościach mechanicznych a szczególnie plastyczności.

Słowa kluczowe: złącza spawane, kruche pękanie, niezgodności złączy spawanych

\begin{abstract}
The vast majority of research into FSW/FSSW weIding tool geometry i.e. the shape of pin and shoulder in horizontal and vertical planes is based on trial and error approach and ideas derived from different case studies. This work may be the basis for mathematical classification of the geometries of tools that are used for joining materials of different mechanical properties, in particular plasticity.
\end{abstract}

Keywords: friction stir welding, friction stir spot welding, process parameters, tools

\section{Wstęp}

Narzędzia wykorzystywane w metodach zgrzewania tarciowego z mieszaniem metali: liniowego (FSW) i punktowego (FSSW) muszą być przystosowane do pracy w stałych środowiskach metalicznych, a więc pokonywać siłami nacisku i tarcia opór postaciowy litych materiałów łączonych. Ekstremalnie trudne warunki ich eksploatacji wymuszają stosowanie na ich konstrukcje specjalnych materiałów, charakteryzujących się wieloma niezbędnymi cechami:

- niewielkimi zmianami właściwości (twardości, struktury, ścieralności itp.) oraz kształtu w wysokich temperaturach,

- niską cieplną rozszerzalnością liniową i objętościową,

- niezmiennością współczynnika tarcia w szerokim zakresie stosowanych prędkości i uzyskiwanych temperatur,

- odpornością na pęknięcia i wykruszenia powierzchniowe,

- odpornością na powierzchniowe naciski miejscowe,

- niewielką wrażliwością na obecność naprężeń przemiennych: rozciągających i ściskających pochodzących od zginania obrotowego,

- możliwością swobodnego kształtowania objętości i powierzchni,

- znaczną trwałością eksploatacyjną i dostępnością cenową. Wybór narzędziowych grup materiałowych na narzędzia FSW/FSSW jest zatem ograniczony i opiera się głównie na stopach wysokowytrzymałych i trudnotopliwych metali takich jak: wolfram, ren, kobalt, tytan, iryd, nikiel lub na materiałach ceramicznych: PCBN, WC i kompozytowych [1 $\div 4]$.
Wynikająca z potrzeb technologicznych konstrukcja tych narzędzi oparta jest oczywiście na ich nieograniczonej lub ograniczonej osiowej symetrii obrotowej. Narzędzia mogą być lite bądź dzielone a te ostatnie mogą zawierać składowe segmenty stałe lub elementy wzajemnie ruchome. Narzędzia mogą być również chłodzone naturalnie lub w sposób wymuszony. Konstrukcja narzędzi FSW/FSSW oparta jest zawsze na współdziałaniu aktywnej części roboczej - zagłębiającej się w materiał i części pasywnej (opory) uniemożliwiającej jego wypłynięcie poza tworzącej się zgrzeinę. Powierzchnia czołowa opory jest czasem profilowana i wtedy spełnia rolę aktywną (rys.1).

Część aktywna (trzpień) w najprostszej wersji jest stożkiem ściętym o różnych kątach tworzącej, wysokości i średnicach podstaw [6]. Trzpienie o bardziej skomplikowanej geometrii charakteryzują się zbliżonymi do gwintowych nacięciami na tworzącej stożka często połączonymi rowkami[7]. Konstruuje się również narzędzia beztrzpieniowe [8].

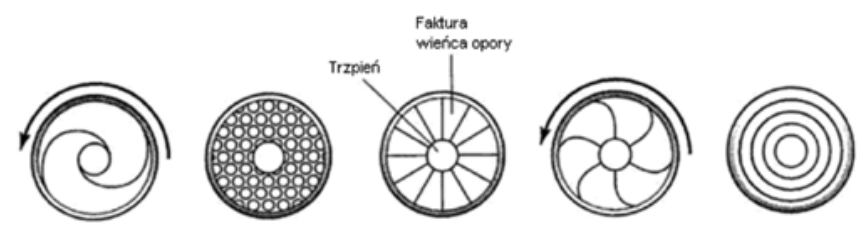

Rys. 1. Faktury wieńca opory [5]

Fig. 1. Texture of the resistance ring.

Dr inż. Kwiryn Wojsyk, adiunkt PCz; dr inż. Krzysztof Kudła - Politechnika Częstochowska. 
Nacięcia i rowki są liniowe lub krzywoliniowe, które najczęściej mają kształt rozwijających się helis, co ułatwia poziomy i pionowy transport mieszanych metalu.

Kształt trzpienia może być bryłą o nieskończonej liczbie symetrii (walca lub stożka ściętego o kołowej podstawie) lub stanowić bryły oparte na którymś z prawidłowych ostrosłupów lub graniastosłupów ściętych. Należy jedynie ich ścianki uwypuklić promieniami o długości boku dla ostrosłupa o podstawie trójkąta równobocznego lub promieniem o długości największej przekątnej w przypadku pozostałych wielokątów podstawy. Można tu wykorzystać zasadę, że okrąg nie jest jedyną krzywą obejmującą pole o stałej szerokości (w przypadku koła jest to średnica). Krzywe oparte na wielokątach foremnych o nieparzystej liczbie boków mają podobne właściwości co okrąg tzn. tworzą pole o jednakowej szerokości, przy czym nie jest ona średnicą (rys.2).

Konstrukcja trzpieni oparta na wielokątach foremnych umożliwia uzyskanie różnych kątów natarcia w płaszczyźnie równoległej do powierzchni elementów podczas wnikania i obrotu narzędzia w zgrzewane materiały. Istotne jest to że w przeciwieństwie do trzpieni stożkowych możliwe jest dostosowywanie kształtu narzędzi do właściwości sprężysto plastycznych łączonych materiałów poprzez „rozwibrowywanie" przyległych do powstającego otworu stref zgrzeiny. Efekt ten jest osiągany przy znacznej wytrzymałości narzędzia.

Zastosowanie typoszeregu narzędzi opartych na trójkącie, pięcio-, siedmio-, dziewięciokącie itd. (rys.3) pozwolą na optymalizację poziomego transportu metalu, przy zastosowaniu pełnej nośności stosowanych narzędzi.

Transport pionowy uplastycznionego materiału regulować można kształtem naciętego rowka (np. gwintu) oraz parametrami procesu [9]. Zastosowanie różnych podstaw ostrosłupów o krzywoliniowym zarysie nie wyklucza trzpieni narzędzi o pobocznicach wklęsłych, płaskich lub wypukłych (rys.5). Intensywność mieszania promieniowego metalu można wyrazić wzorem (1), której zmiany w zależności od kształtu trzpienia o budowie opartej na wielokątach uwypuklonych przedstawia rysunek 4 .

$$
\left.M \%=100 \%-\% R=100 \%-\frac{R 2-R}{R 2} \cdot 100 \%[\%] \quad 1\right)
$$

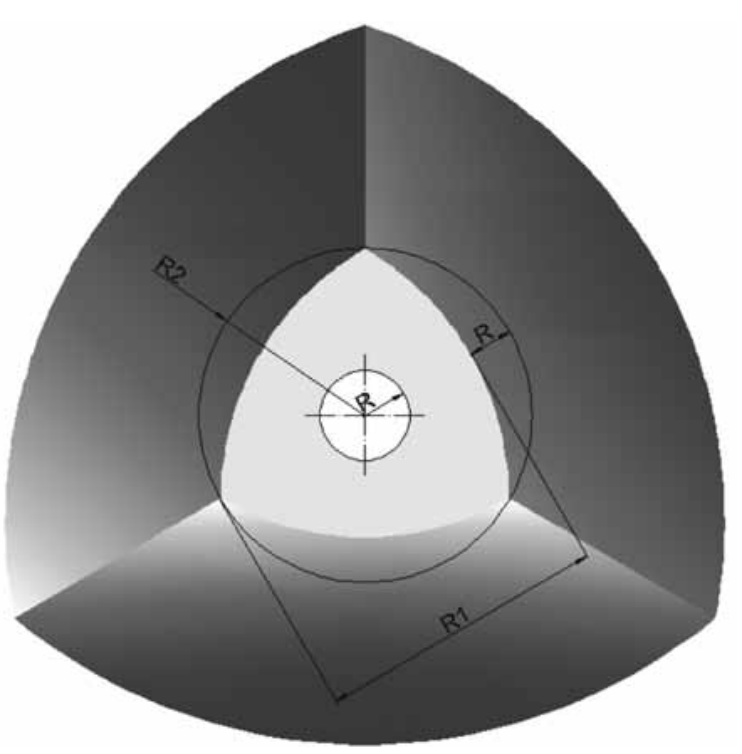

Rys. 2. Widok podstawy trzpienia opartej na uwypuklonym ostrosłupie foremnym o podstawie trójkąta. R1 - najmniejszy promień krzywizny pobocznicy równy grubości narzędzia, R2 - promień okręgu opisanego na minimalnym przekroju narzędzia, $\mathrm{R}$ - amplituda ruchów poziomych mieszanego metalu.

Fig. 2. View of tool base on pyramid shape
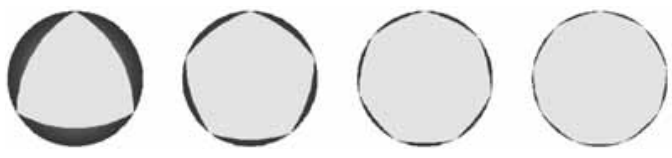

Rys. 3. Widok podstaw trzpieni opartych na uwypuklonych wielokątach foremnych o nieparzystej liczbie boków

Fig. 3. View of tool base

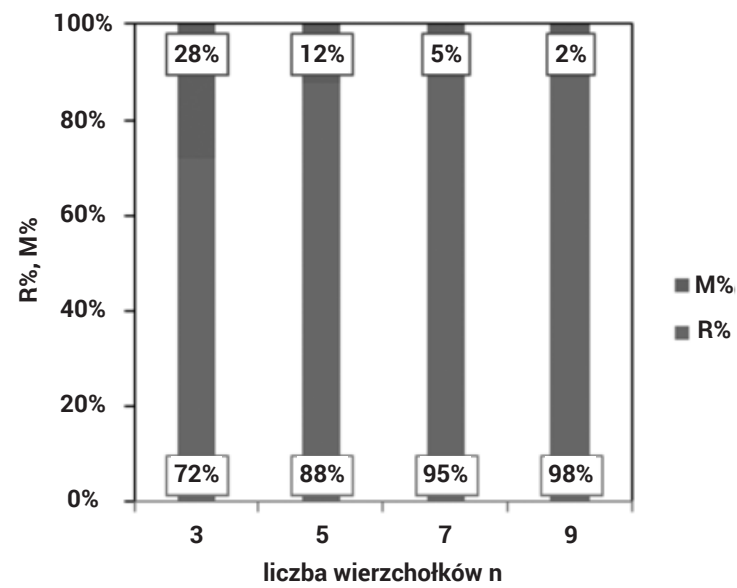

Rys. 4. Intensywność M\% promieniowego mieszania metalu Fig. 4. The intensity $\mathrm{M} \%$ of radial stiring in metal

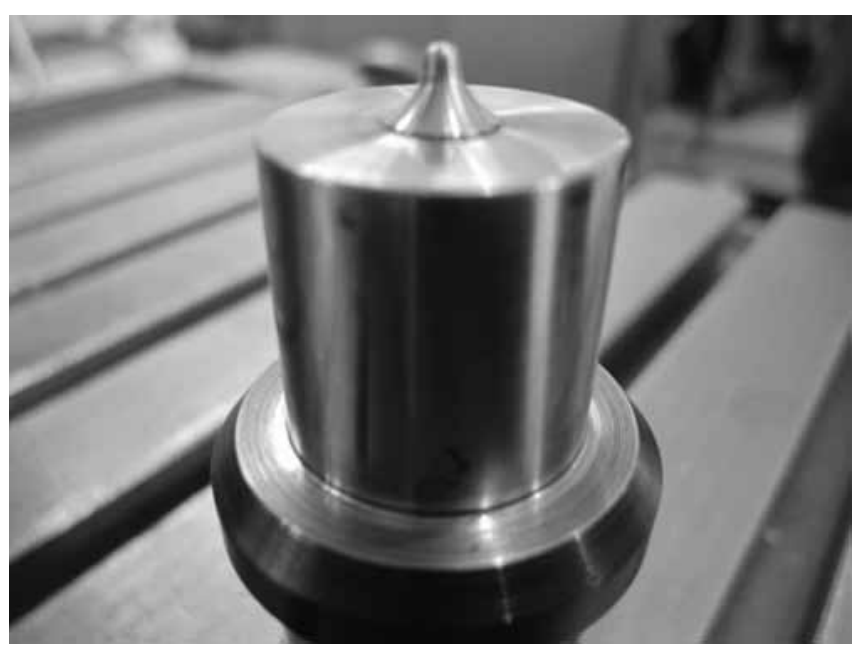

Rys. 5. Narzędzie do zgrzewania FSW/FSSW z hiperboloidalną pobocznicą trzpienia

Fig. 5. Tool for friction welding with hyperboloid shape
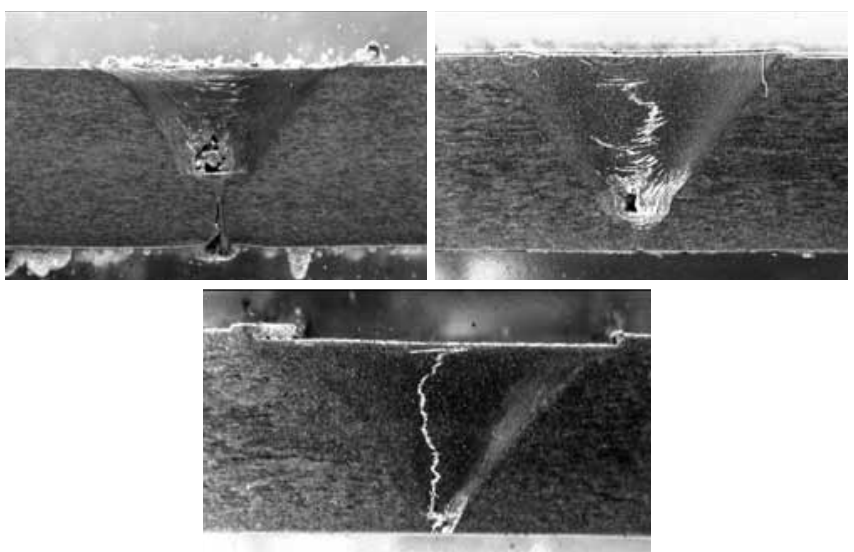

Rys. 6. Fazy zanurzenia narzędzia o wklęsłej pobocznicy trzpienia oraz tworzenie niezgodności wewnętrznych w złączu zgrzewanym FSW

Fig. 6. Tool penetration phase with concave shape and generation of imperfections in FSW welded joints 
Podobnie kształtować można pobocznice profilowe (z nacięciami na pobocznicy), które w najprostszych przypadkach mają krzywiznę zerową, lecz mogą być również wklęsłe lub wypukłe. Poprzeczne nacięcia na pobocznicach mogą mieć różne kształty i zarysy ich wrębów, jak również wznosić się pod róż- nymi kątami do osi trzpienia i zmieniać stopnie zagęszczenia.

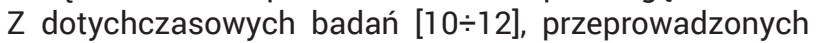
w Zakładzie Spawalnictwa P.Cz., wynika, że trzpienie o wklęsłej pobocznicy mogą tworzyć zgrzeiny zawierające w swej objętości pustki gazowe (rys. 6).

\section{Wnioski}

Konstrukcje narzędzi do zgrzewania FSW można opisać na zasadach ograniczonej symetrii osiowej wykorzystując zróżnicowanie uplastyczniania łączonych materiałów podczas zgrzewania.

Oparcie budowy narzędzi na podstawie szeregu wielokątów foremnych o nieparzystej liczby boków umożliwia dostosowanie ich konstrukcji do plastyczności metali łączonych bez osłabiania przekroju poprzecznego narzędzi rowkami do transportu metali.

Opisane konstrukcje narzędzi eliminują powstawanie tzw. martwych stref mieszania, a więc doprowadzą najprawdopodobniej do tworzenia złączy zgrzewanych o wysokich cechach eksploatacyjnych.

\section{Literatura}

[1] Matt Collier, Russell Steel, Tracy Nelson, Carl Sorenen I Scott Packer. Grade Development of Polycrystalline Cubic Boron Nitride for Friction Stir Processing of Ferrous Alloys. Materials Science Forum, 2003, vol. 426-432, str. 3011-3016.

[2] Huijie Liu, Li Zhou, Yongxian Huang, Qiwei Liu: Study of the Key Issues of Friction Stir Welding of Titanium Alloy. Thermec, 2009.

[3] Murray W. Mahoney, Christian Fuller, William H. Bingel, Michael Calabrese: Friction Stir Processing of Cast NiAl Bronze. Materials Science Forum, vol. $539-543$ (2007), str. 3721-3726.

[4] R. Rai, A. De, H. K. D. H. Bhadeshia, T. DebRoy: Review: Friction stir welding tools. Science and Technology of Welding and Joining, 2011, vol. 16, str. 325-342.

[5] Rajiv S. Mishra, Murray W. Mahoney. Friction Stir Welding and Processing. ASME International, 2007, str. 1-37.

[6] Pietras A.,Węglowska A.,Miara D.:Wpływ warunków zgrzewania FSW na proces tworzenia złącza z materiałów różniących się właściwościami fizycznymi .Przegląd Spawalnictwa 11/2013 str. 48-57.

[7] Kalemba J.,Dymek S.:Mikrostruktura i właściwości połączeń stopów aluminium wykonanych metodą zgrzewania tarciowego z mieszaniem materiału zgrzeiny. Przegląd Spawalnictwa $7 / 2011$ str. 45-50.
[8] Pietras A.,Węglowska A.,Rams B.,Węglowski M.:Nowa technologia zgrzewania tarciowego rury z pokrywą.Przegląd śpawalnictwa 11/2011 str. 29-36.

[9] Kalemba J.,Miara D.,Kopyściański M.,Krasnowski K.:Charakterystyka złączy stopów aluminium serii 5xxx i7xxx wykonanych metodą zgrzewania tarciwoego z mieszaniem materiału. Przegląd Spawalnictwa 2/2015 str. 30-36.

[10] Kudła K. Wojsyk K. Kucharczyk Z.: Properties of Overlap Joints WeIded by the Friction Stir Welding Method. Metal Forming Vol.24 nr 3, str. 179-191.

[11] Kudła K. Wojsyk K. Adamus K: The Properties of Spot-Welded Joints Produced by the FSSW and RFSSW Methods. Metal Forming Vol. 24 nr 3, str. 193-203

[12] Wojsyk K.: Raport. nt. Analiza możliwości łączenia elementów cienkościennych za pomocą zgrzewania tarciowego z przemieszaniem FSW złączy doczołowych. Zadanie badawcze 15: Niekonwencjonalne technologie łączenia elementów konstrukcji lotniczych (niepublikowany). 